\title{
"Olympism" and Olympic Education in Greek Antiquity
}

\author{
Jiř́ Koư̌il \\ Faculty of Arts, Masaryk University
}

\begin{abstract}
This paper deals with basic points which comprise Olympic and "sport" education in the Greek antiquity. Until the emergence of professionalism in ancient athletics was the essence of "sport" education and Olympism the areas known as free "sport", nudity, construction of "sports" buildings, organizing of many games and relation of society to the Olympic winners as well as leading the citizens to cultural and philosophical ideals. The education itself to the Olympic Games and "sport" had an important role in ancient Greece. Victory in the Panhellenic Games was very important not only for the victors as individuals, but also for their lineage and the city-state. Each victor entered the next level, which was close to the heroes and gods. They acquired semi-divine status and the homages for them by all society and mainly by the city-states were greatly important for cultural outputs and conception of all society. The influence of victors on youth was huge and this influence was one of the most important educational parts of all ancient Greek culture. The winners of great Panhellenic Games, especially the

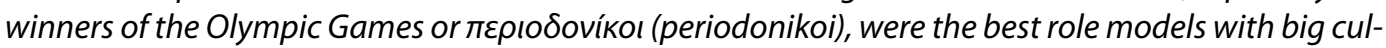
tural power and the best examples for youth. Successes of ancient athletes supported sport education of young Greek boys, thus also the military training and this conception created better warriors and defenders of the city-states.
\end{abstract}

Key words: Games, Greek antiquity, nudity, olympism, olympic education, sport buildings, winners.

\section{INTRODUCTION}

This contribution deals with basic points which comprise Olympic and "sport" education in the Greek antiquity. The use of the word Olympism for antiquity is problematic because it was created afterwards, but there were many similar tendencies among them. Especially the name itself is derived from ancient Olympia, where the Olympic Games had their origin. Furthermore, the education itself to the Olympic Games and "sport" ${ }^{1}$ had an important role in ancient Greece.

Victory in the Panhellenic Games (Olympia, Delphi Isthmos, Nemea) was important not only for the winners as individuals, but also for their lineage and the city-state. Many tyrants, often from Magna Graecia, mainly from Sicily, used this to promote their own political regime; therefore sometimes they also bribed the gifted $\dot{\alpha} \theta \lambda \eta \tau \alpha l$ (athlétai) or victors to move and compete on the games for their name and community.

\section{METHODOLOGY}

This paper is a historical contribution. The data was gained mainly from primary sources, relevant professional literature and ancient arts.

Used methods were gathered from the primary and secondary sources. The methods that were used were comparation method, biography method, progressive method, direct and indirect methods.

\footnotetext{
Or rather the $\dot{\alpha} \gamma \dot{\omega} v$ (agon).
} 
As the way of processing data, results from primary and professional literature and ancient arts, as well as criticism of the sources, interpretation and synthesis were compared.

Sections of the connection between Olympism and Olympic Education in ancient Greece The importance of the Panhellenic Games and "sport" led to a great state support, which was manifested mainly in the following sections:

1. free "sport",

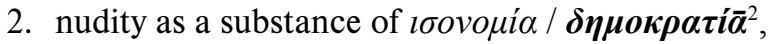

3. construction of "sports" buildings,

4. organizing of many all-Greek and local games,

5. promotion and support of the winners.

At the same time, these areas were basic for the Olympic education in Greek antiquity and each $\pi \dot{\lambda} \lambda l \varsigma$ (polis) placed considerable emphasis on them, because "sport" was associated with $\tau \tilde{\mu} \mu \dot{\eta}$ (time, honour) and other virtues, which spread through Greek society, from religion to everyday life and from art to politics and warfare. Mentioned areas above and upbringing to the true types / ideals of Greek culture were the essence of the "Olympism" and Olympic education in Greek antiquity until the uprise of the professionalism in "sport".

\section{Free "sport"}

Theoretical instruction was often held in ancient Greece in private schools and it was defrayable, so it depended on the parents of the boys what education they were able to provide them with. These schools were not to be open after sunset and before dawn. But that was not a rule for all Greece; the opposite was e.g. Sparta, where private schools did not exist. Beyond theoretical and musical education here was also $v v \mu v i \kappa o ́ \varsigma$ (gymnikos) education, that contained running, jumping, wrestling, discus throw, javelin and swimming. The $\pi \alpha \lambda \alpha i \sigma \tau \rho \bar{\alpha}$ (palaistra) was for fourteen years old boys and unlike other schools, the $\pi \alpha \lambda a i \sigma \tau \rho \bar{\alpha}$ was free. After completing of this education, young boys from wealthy families could continue in further education; they had a choice of philosophy,

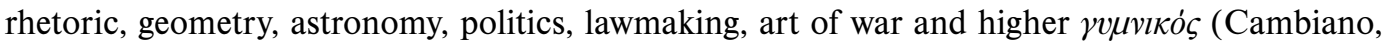
2005; Śílený, 1947; Zamarovský, 2003).

The reason was to allow access to all sports fields and to make sport free so even the poorest could participate. But the main reason for the big expansion of "sport" in Greece was the need for excellent physical preparation of Greek aristocracy as defenders of the homeland (in a sense of their dual identity - protection of their own $\pi \dot{\lambda} \lambda l \varsigma$ and protection of Greece) against the external and internal enemies. In addition to alien attempts to subjection the Greeks, there was also a great danger by slaves, whose number was often higher than the number of freemen and semi-freemen. In physical violence "and in a weapon, held by a muscular and trained hand, was the most effective guarantee of the unlimited obedience of the exploited men and lordly welfare" (Sábl, 1960, p. 12: translated from the Czech). Without support of "sport", physical exercises and military training, this ruling class would be destroyed.

From the above-mentioned reasons and not only from it, "sport" and physical exercises were free for the Greeks. The Greeks had to pay for education and acquirement, but not for "sport", if they had time, they could go to the $\boldsymbol{\gamma} \boldsymbol{v} \boldsymbol{\mu} \boldsymbol{v} \dot{\alpha} \sigma \boldsymbol{\sigma} \boldsymbol{v}$ or the $\pi \alpha \lambda \alpha i \sigma \tau \rho \dot{\alpha}$ and exercise whenever. This situation is not very realistic nowadays, because modern states and countries will never support sports so much as long as the commerce, the $\pi \lambda \varepsilon o v \varepsilon \xi i a ́$ (pleonexia) and the $v \beta \beta \imath \varsigma$ (hybris) prevails here.

Isonomia / demokratia. 


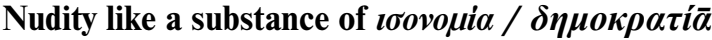

Ancient Greeks competed naked. Originally, athletes had their flank and waist covered by a loincloth, so called $\zeta \tilde{\omega} \mu \alpha, \delta i \alpha \zeta \zeta \omega \mu \alpha$ or $\tau \rho i \beta \omega v^{3}$, but later they removed it (Golden, 2005, p. 131). According to the legend, it was because of the runner Orsippus/ Orhippus of Megara (and after him also because of Acanthus, a long-distance runner from Sparta) in 8th century B. C. at Olympia, whose $\delta l \dot{\alpha} \zeta \omega \mu \alpha$ fell during the race; but he continued in the running $\dot{\alpha} \gamma \dot{\omega} v$ and won. The $\dot{\alpha} \theta \lambda \eta \tau \alpha l$ gradually followed his example and nudity became a rule (Newby, 2006; Potter, 2012). The source of this legend was Orsippus s tomb with Simonides's epigram (Hyde, 1921). According to other sources, mainly the Spartans expanded this practice. At the beginning of the archaic period the Spartans wore a light garment during the exercise, which they undressed later. Artistic displaying of the naked Spartans and Greek $\dot{\alpha} \theta \lambda \eta \tau \alpha l$ was a realistic depiction of the reality; it was not only artistic and heroic depictions. The introduction of nudity had also something to do with Greek mythology and rituals, its sense was largely religious (Jirásek, 2009); it was understood as an expression of culture and not as something to be ashamed of - to be ashamed was a sign of barbarism. Its significance and meaning was given by a set of values attributed to nudity, cultural and social environment (Jirásek, 2009). Modern historians derive the origin and genesis of nudity from prehistoric hunting, initiating of young boys and admiring of a male body (Golden, 2005, p. 111-112).

The meaning of nudity was not only religious and practical, but also symbolic; here the inequality was deleted. An ordinary naked young man or any man competing against a naked aristocrat was equal to him at this moment, there was nothing unnatural that would make them different. An aristocrat could be equal to a common slave if they clashed in the gymnasion ( vvpvórolov). The men were not separated by their expensive dress or badges of dignity and their roles, but only by their own body shape, strength, speed, endurance and dexterity; when the $\dot{\alpha} \gamma \dot{\omega} v$ started, they were separated only by their own $\dot{\alpha} \rho \varepsilon \tau \dot{\eta}$. Also the last boy could compete with the noblest and defeated

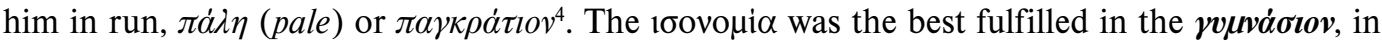
the place of the clash of people where at the same time everyone was socially iroos (isos). The rvuváolov become an important means of increasing of human pride and equality. We can observe the first elements of the $\delta \eta \mu о к \rho \alpha \tau i \bar{\alpha}$ not in the field of society in general, politics, philosophy, or science, art, paideia $(\pi \alpha l \delta \varepsilon i \alpha)^{5}$, but in the field of ancient physical exercises through nudity.

The importance of nudity in Greek world was confirmed also by the significance of the term for nudity itself, rvuvós, gymnos (traditionally was the term yvuvó $\zeta$ understood as naked, meaning unarmed, which also refers to the concept of Homer's expression $\boldsymbol{\gamma} \boldsymbol{v} \boldsymbol{\mu} \boldsymbol{v} \boldsymbol{\zeta} \zeta$, as "without weapon”). This term was also a part of the name of some festivities like for example the Gymnopaedia and

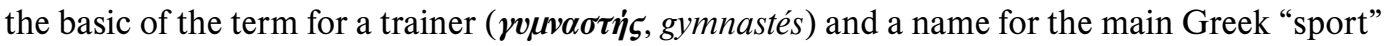
competitions ( $\gamma v \mu v i \kappa o ́ \varsigma ~ a ́ \gamma \dot{\omega} v$, gymnikos agon).

\section{Construction of "sports" buildings}

"Sports" buildings were an important, inherent and essential part of Olympic education in the

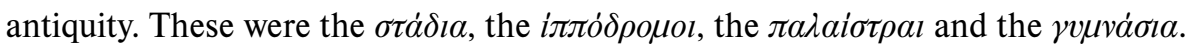

The basic construction of Greek "sport" was the $\sigma \tau \dot{\alpha} \delta l o v$, which formed a race track of a rectangular shape at one end, the track was semicircularly rounded and had different lengths:

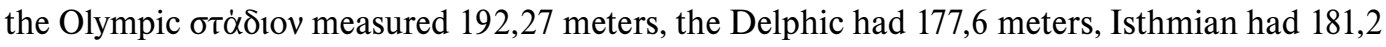

\footnotetext{
3 Spartan short coat.

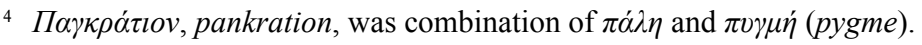

5 The word $\pi \alpha l \delta \varepsilon i \alpha$ (a game) was derived from the word $\pi \alpha \tilde{\imath} \varsigma$, pais (a child). The opposite was the term $\sigma \pi o v \delta \dot{\eta}$, spondé (serious) as the activities which were practiced by adults (Cambiano, 2005). It was actually about upbringing, the life struggle of the soul for self-liberation from the ignorance of the supreme good, which is the trellage on the way to true bliss - Plato understood this ignorance as a source of all evil (Jaeger, 1986).
} 
meters, Athenian had 184,9 meters, Miletian had 177,4 meters, Aiginian had 196,8 meters, attic measured 164 meters, ... (Kössl et alii, 1982; Prach, 1998; Zamarovský, 2003, p. 55), and the iллó $\rho о \mu о \varsigma^{6}$, which was built for equestrian races. Its length was various, but one circle measured approximately 1125-1200 meters.

Other construction associated with Greek "sport" was the $v v \mu v \alpha$ a an open and covered running track where was a place for long jumps, throws and boxing, a place for ball games and premises for a body care and hygiene as dressing rooms, bathrooms, swimming

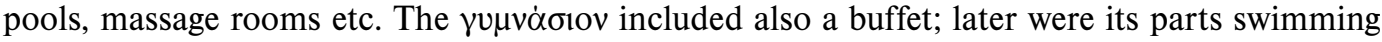
pools and a spa. Hermes the god was the inventor of this building (according to the myth) and

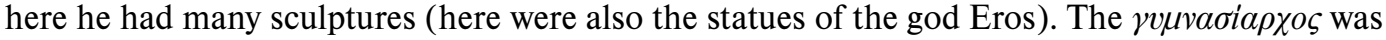

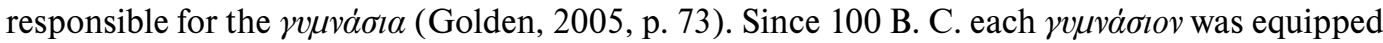
with the hypocaustum (special central heating). In each (even small) city were usually several of these buildings (e.g. the Academy, the Lyceum, the Cynosarges - also for the underprivileged citizens (Grexa, 2009; Kössl et alii, 1982; Olivová, 1988; Zamarovský, 2003). The vvuváolov was to develop the $\dot{\alpha} \rho \varepsilon \tau \dot{\eta}$ of the $\dot{\alpha} \theta \lambda \eta \tau \alpha l$, there were also lessons for teenagers, who were twelve years old. The $\dot{\alpha} \theta \lambda \eta \tau \alpha \iota$ in the $\gamma v \mu v \alpha \dot{\sigma} \sigma o v$ exercised and strengthened naked, only lubricated with oil. Entrance to the $\gamma u \mu v \dot{\alpha} \sigma i o v$ was a sign of social differentiation. Its main development was associated with increasing leisure time ( $\sigma \chi 0 \lambda \dot{\eta}$ ) of free (also poorer) inhabitants, who visited it often after their

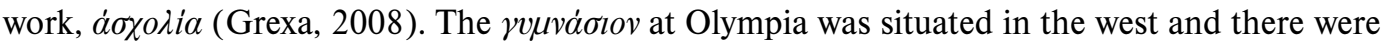
two backyards. The $\dot{\alpha} \theta \lambda \eta \tau \alpha l$ in Olympia were preparing for competitions here. Vitruvius described the rvpuváolov in more details: "In palaestris peristylia quadrata sive oblonga itasunt facienda, uti duorum stadiorum habeant ambulationis circumitionem, quod Graeci vocant jiavios, ex quibus tres porticus simplices disponantur, quarta, quae ad meridianas regiones est conversa, duplex, uti, cumtempestates ventosae sint, non possit aspergo in interiorem partempervenire. Constituantur autem in tribus porticibus exhedrae spatiosae, habentessedes, in quibus philosophi, rhetores reliquique, qui studiis delectantur, sedentes disputare possint" (Vitr. 5.11.1-2). ${ }^{7}$ The running track in the vvpróolov was called $\xi v \sigma \tau o \dot{ } \varsigma$, xystos, (from $\xi \dot{v} \omega$, adjust); it referred to Heracles, who weeded out the bush in Olympia because of runing (Sábl, 1968).

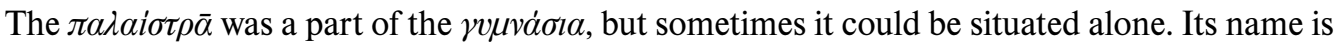
derived from a Greek verb $\pi \alpha \lambda \alpha i \omega$ (palaio), I wrestle ( $\pi \dot{\alpha} \lambda \eta$, wrestling). Here were also the $\alpha \dot{v} \lambda \eta \tau \alpha l$

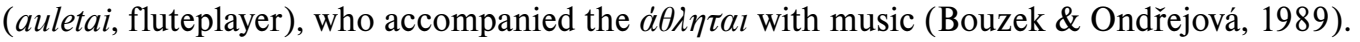

\section{Organizing of many all-Greek and local games}

In ancient Greece there were organized many games. The most famous of them were the Great Panhellenic games at Olympia, Delphi, Isthmos and Nemea and also the Great Panathenia. But there were also a number of larger and smaller local games.

We also know, for example, about the Boedromia as the celebration of the victory of Theseus over the Amazons or to the honour of Apollo Boedromios (Hurry to help in distress), the Heracleia in Marathon, Thebs, Argos, Samos, Syros). In Argos took place e.g. the Sthenia and the Heraean Games; in Megara the games to honor Apollo, the Pythaea and the Alcathoa, the son of Pelops; in Eleusis the games to honor the goddess Demeter; in Rhodos the games the Tlepolemia to honour

\footnotetext{
6 From the $i \pi \pi o \varsigma$, the horse and the $\delta \rho o ́ \mu o \varsigma$, run or race track.

7 "I think it best to set forth the traditional way, and to show ob long peristyle in a palaestra should be so formed that the circuit of it makes a walk of two stadia, a distance which the Greeks call the diovios. Let three of its colonnades be single, but let the fourth, which is on the south side, be double, so that when there is bad weather accompanied by wind, the drops of rain may not be able to reach the interior. I think it best to set forth the traditional way, and to show ob long peristyle in a palaestra should be so formed that the circuit of it makes a walk of two stadia, a distance which the Greeks call the diavios. Let three of its colonnades be single, but let the fourth, which is on the south side, be double, so that when there is bad weather accompanied by wind, the drops of rain may not be able to reach the interior" (translation by M. H. Morgan, 1914).
} 
Tlepolemus, the son of Heracles and Astydameia, the founder of settlements on the Rhode Island, who died before Troy; in the spring there was a feast of the god Helios, the Helieia (a part of these

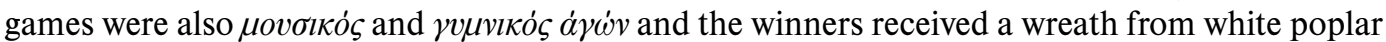
branches; in Delos took place the Delia and the Apollonia or the lesser Delia (these games took place also in Lesbos); in Lesbos (same as in Naxos, Tenedos and Chios) took place the Dionysia; in Thebes was the Iolaea or Iolaia to honour Iolaus, a friend of Heracles; in Epidaurus took place the Asklepia. The games were also in Ephesus, Smyrna, Puzzuoli, Macedonia, Cyrene, Sicily etc. In Plataea took place the Eleutheria (celebrated every five years as a celebration of the victory over Persia, an important race was ó $\pi \dot{\varepsilon} i \tau \eta \zeta$ here), in Lebadeia in Boeotia was celebrated the Basileia (as a celebration of the defeat of the Spartans at Leuctra in 371 B. C.; this festival was also in the other places) and the Trophonian. After the Battle of Actia, there were held the Actia Games. In Piraeus in Athens, in Sparta (for girls) and in Eleusis took place the Dionysia. Games were held also in Salamis, Pergamon, Tanagra, Koroneia (the Pamboeotia - the all-boeotians games), Amykles (the Hyakinthia), Sparta (the Carnea, the Leonidaia, the Urania). The games founder was also Alexander the Great and the Diadochi, e.g. the Demetria, the Alexandria, the Eumenia, the Ptolemaia, the Seleukeia, the Philataireia, the Attaleia etc.; likewise also the Romans (Sábl, 1960).

\section{Promotion and support of the winners}

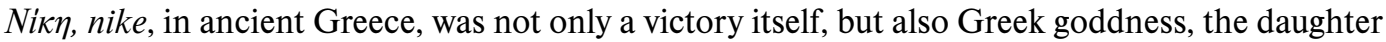
of Pallas (Combat), the Titan, and Styx (Hatred), her sister was Bia (Force) and her brothers were Kratos (Strength) and Zelos (Emulation/Endeavor). In the war between gods and titans she fought for Zeus (Hes., Th. 383-400). The goddness was often depicted as standing or a flying creature. She held a winner's wreath or a ribbon in her hands and brought this to the victors. Thus, she was the nikephoros, "bringer of victory" (Weiler, 2012, p. 22).

The success of ancient Olympic victors was something godlike. With the victory at Olympia, ancient athletes entered into the significance level, which was similar as the stratum of the gods and demigods. Equivalent of this great glory was only possible to find on the field of warfare. On the battlefield ancient Greeks could gain the collective glory. This collective glory and individual glory gained from the great games, mainly at Olympia, was something more than ordinary parts of Greek lives. Here, nothing was as highly valued as fame and inside of fame was really immortality (Drees, 1968, p. 101). ${ }^{8}$ The victors gained a great fame and they were hailed with a hymn to Heracles by Archilochus of Paros at Olympia (Scheiner, 1891, p. 165). The celebration of the victors with hymns, etc. was a favourite part of this act - e.g. Xenophon of Corinth ${ }^{9}$, the winner of the foot-race and pentathlon in 464 BC (79th Olympic Games) was welcomed at home by singing before the city gate and then by the hymn before the temple of Apollo, which was lead and created by Pindar. Here, we can mention also warlike (e.g. $\left.\dot{\alpha} v \delta \rho \varepsilon i \bar{\alpha}^{10}, \dot{\alpha} \rho \imath \tau \tau \varepsilon i \bar{\alpha}^{11}\right)$ and sports (e.g. $\left.\dot{\alpha} \rho \varepsilon \tau \dot{\eta}^{12}, \kappa \alpha \lambda о \kappa \alpha \dot{\alpha} \alpha \theta i \alpha\right)$ ideals, which were equally the basic ethical ideals that created all society in Greek antiquity and were strongly connected with fame. Sport and Olympia were parts of the Greek miracle. The importance of the Olympia's victories played an important role in the

\footnotetext{
8 "When they died they went down to their joyless existence among the shades. Their only hope of immortality therefore was to perform some great deed which would live on in the minds of men. The deed was not important in itself. What mattered was that it should be celebrated by the world"... "Their names lived on when they themselves were dead" (Drees, 1968, p. 101).

9 It is possible, that famous Myron's Discobolus was the statue of Xenophon of Corith (Kourìl, 2015, p. 120-121).

${ }^{10}$ Andreia was derived from the term $\alpha \dot{\alpha} \delta \rho o ́ \varsigma$, man; courageousness, bravery, red-blooded power; fortitude displayed in the struggle.

${ }^{11}$ Aristeia was a Greek term for unusual valiant behaviour in the battle, heroism, valor, daring, rare proof of courage; as compared to the term aristeion, $\dot{\alpha} \rho \imath \tau \tau \bar{\imath} o$. Thus, heroism and also honor, reward, victorious prize for the biggest valour in the battle (Kouřil, 2016, p. 15; Prach, 1998, p. 86).
}

${ }^{12}$ Arete $=$ excellence, athleticism, proficiency. 
propagation of each $\pi \dot{\partial} \lambda l \varsigma$ (polis) and its political system. Demonstration of their power and superiority was also important for the education of the youths. The winner's example and successes were emulated by others, especially by the youth. This trend was supported and promoted by the elites. The elites understood very well these principles and they knew that the public celebration of the victors and the advantages provided to them were the best educational examples for young people. The relationship of the ancient Greek culture and society to the Olympic winners was the basis of Olympism and Olympic education in antiquity. Thus, the transition from the status of an ordinary person / $\dot{\alpha} \theta \dot{\lambda} \eta \dot{\eta} \zeta$ to the highest human level under the gods and demigods or mythological heroes was highlighted.

The reward $\left(\tilde{\alpha} \theta \lambda o v\right.$, athlon $\left.^{13}\right)$ in the most famous and the greatest ancient Greek games was a wreath - an olive wreath at Olympia, a celery or parsley wreath at Nemea, a laurel wreath at Delphi, and a pine wreath at Isthmia (Paus. 5.7.6-7, 8.48.2-3, 10.7.8; Pind., I. 2.15-17; Pind., $O$. 13.33-34; Plut., Mor. 676f; Plut., Quaes. Conv. 5.3.1). The winner also received a palm branch and a red ribbons symbolizing his victory, which were tied around his head and arm or leg. The olive wreath, called кótıvos (kotinos), was made from the sacred olive tree, which the Greeks named Kallistefanos ("donor of the beautiful wreaths"). Either the goddess Pallas Athena gave the tree to the Greeks or Heracles planted it there (Zamarovský, 2003). The Greeks believed that this wreath had a supernatural power and the victory provided protection by Zeus himself. The kó $\tau$ vo also contained a huge honor and peak of earthy bliss. The winners could be also honored in the form of festive poems (epinikions) and a statue could be built in their hometown or in the place of their victory, or in both (Kössl et alii, 1982; Newby, 2006). The triple victors were allowed to erect realistic statues, called iconica. ${ }^{14}$ The significance of the statues of the prominent people, especially the winner from Olympia confirms a funny story about an excellent Greek athlete, Theagenes of Thasos, who (when he was 9 years old) stole the bronze statue of a god from $\alpha$ yopá (agora). However, later, he was an Olympic victor himself and had several statues made. One of his statues, after his death, fell and killed one of Theagenes'enemies, who was walking to this statue and was flogging it everyday (Golden, 2005, p. 163).

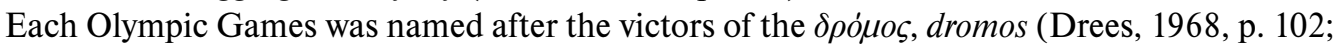
Schöbel, 1965, p. 116). The winners could eat for free (paid by the state) until the end of their life (in the $\pi \rho v \tau \alpha v \varepsilon i \tilde{i}$, prytaneion) and hold important political, religious, etc., positions in the state. In the struggle of battle (in the $\phi \dot{\alpha} \lambda a \gamma \xi$, falanx) victors were stationed in honorable places. Victors also had a special honorary place in the theatre (Athen., Deipnos. 6.237) and during festivals.

The Olympic victor was the best man similar to a Homeric hero; in $\tilde{\alpha} \theta \lambda \alpha \dot{\varepsilon} \pi i$ П $\dot{\alpha} \tau \rho \circ \kappa \lambda \omega \imath$ only the best heroes competed and won. Exmaples include: Diomedes, the king of Argos ( $\sigma v v \omega \rho i \varsigma)$, Epeius $(\pi v \gamma \mu \eta \dot{\eta})$, Aias/Ajax the Great - Odysseus $(\pi \dot{\alpha} \lambda \eta)$, Odysseus ( $\delta \rho \dot{\alpha} \mu \sigma \varsigma)$, Diomedes - Aias/

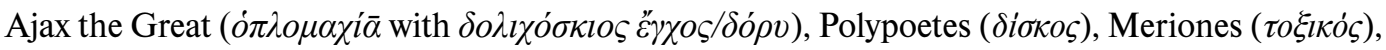
Agamemnon (

The winners could choose to create the epinikion at the expense of their own, their family or poleis ( $\pi \dot{\lambda} \lambda \varepsilon l \zeta)$ and in which he was often filiationed with god or gods. These were also one of the appropriate means of youth education (the Olympic Education). Their most famous author was Pindar (others were Bacchylides and Simonides), and in almost every Olympic epinikions, Pindar celebrates the winner and his family or $\pi \dot{\lambda} \lambda l \varsigma$. The winner thus became an ideal example for young boys, the role model and one of the best citizens, who spreads the glory not only his own and his family but also his $\pi \dot{\lambda} \lambda \iota s$.

\footnotetext{
${ }^{13}$ Originally, it was a specification for a loot in the battle.

14 "Effigies hominum non solebant exprimi nisi aliqua inlustri causa perpetuitatem merentium, primo sacrorum certaminum victoria maximeque Olympiae, ubi omnium, qui vicissent, statuas dicari mos erat, eorum vero, qui ter ibi superavissent, ex membris ipsorum similitudine expressa, quas iconicas vocant" (Plin., NH 34.9.4).
} 


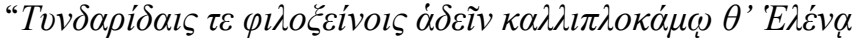

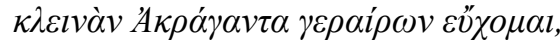

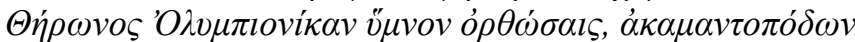
$i \pi \pi \omega v \not \alpha \omega \tau o v "$ (Pind., O. 3.1-4a). ${ }^{15}$

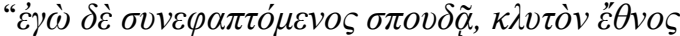

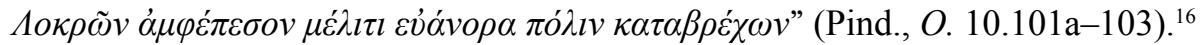

The Olympic victory had for the winner a tremendous prestige; just as important for the athlete's $\pi \dot{\lambda} \lambda l \varsigma$ - as the name of the city-state was next to the name of the winner. The $\pi \dot{\lambda} \lambda l \varsigma$ through its $\dot{\alpha} \theta \lambda \eta \tau \alpha i$ gained political significance and influence and at Olympia its official delegations / ambassadors $\left(\theta \varepsilon \omega \rho{ }^{17} l^{17}\right)$ had the opportunity to sign agreements of the international significance.

For the winners spoke their performance, movement; they did not need to boast with external features like wealth or political power. Their wealth was something higher than ordinary things. Their movement leading to victory was "the result of the dialogue with the Gaia" (Hogenová, 2000, p. 150). After the ceremonial procession, the winners were hosted in the $\pi \rho v \tau \alpha v \varepsilon \tilde{i} o v$. Taxes were largely forgiven to them in their birthplace and given honor similar to kings and gods. Some of them were receiving monthly or annual allowance and later, some famous winners received payment by the organizers of lesser games when they participated in these events. The $\pi \dot{\lambda} \lambda \varepsilon l \zeta$ were extremely proud of their Olympic victors and a lot of cities pampered them and supported and subsidizing the trainings and travels of these men or their other promising and gifted athletes (Pleket, 2012, p. 132-133). The famous winners were also often released by the enemy after a lost battle (Bouzek \& Ondřejová, 1989); it was an example of famous $\pi \alpha \gamma \kappa \rho \alpha \tau \iota \alpha \sigma \tau \dot{\eta} \varsigma$ (pankratiastes, pankratist) Dorieus, the son of Diagoras, who was captured and released by the Athenians (Paus. 6.7.1-7; Thuc. 3.8.1). The victors were also the leaders of some state expedition (e.g. Euthycleus of Locri, Gaius Perelius Aurelius Alexander). The winners were sought by the rulers of some $\pi \dot{\lambda} \lambda \varepsilon \iota \varsigma$ and empires as suitable husbands for their daughters (Osborne, 2010) or they were friends of kings and elites (e.g. Milo, Dexippus). The winner was dressed in purple ${ }^{18}$ and he rode a chariot with white horses, through not a gate, but a newly made hole in the wall. It was to refer to the fact that this missing part of the wall filled the bodies of the winners who covered it and protected it against enemy attack (Tyrš 1968). For example Suetonius mentioned that this homage was utilized by Nero, the Roman emperor (Suet., Nero 25). Exainates from Akragatos was accompanied to the city by 300 two-team chariots with white horses (Diod. Sic. 12.82.1, 13.33.1; Scheiner, 1891, p. 166). The victor's entrance to the city was simultaneously a triumphal procession (similar to the Roman triumphs ${ }^{19}$ ) with flowers and twigs ( $\phi v \lambda \lambda$ ioßoגia, fyllobolia: Kefalidou, 1999, p. 96; Trianti \& Valavanis, 2015, p. 130) - assurance of fertility and strong genus of victors. This shower of flowers and leaves probably also occured at Olympia and the victor was lifted and carried on

\footnotetext{
15 "I pray that I may be pleasing to the hospitable sons of Tyndareus and to Helen of the beautiful hair while I honor renowned Acragas by raising my song in praise of Theron's victory at Olympia won by the choicest of horses with untiring feet" (translation by D. A. Svarlien, 1990).

16 "While I, earnestly lending my hand, have embraced the famous tribe of the Locrians, showering with honey their city of fine men" (translation by D. A. Svarlien, 1990). Also e.g. Pind., O. 2.52-56; 7.20-27, 76-88; 11.16-20; $13.1-5 ; 14.17-24$.

${ }^{17}$ From $\theta \varepsilon \omega \rho \tilde{\omega}$, to observe, to be a spectator or a messenger at a feast.

${ }^{18}$ Purple was used for a high status. With the ancient Olympic victors there was lots of symbolism - purple and red color, wreaths, the $\varphi v \lambda \lambda o \beta o \lambda i \alpha$, etc.

${ }^{19}$ For the Greeks, the victory at Olympia was more important than the triumphs over the Romans - "Hoc est apud est Graecos, quoniam de eorum gravitate dicimus, prope maius et gloriosius quam Romae triumphasse” (Cic., Flac. 13.31).
} 
the shoulders of friends and spectators during the procession. The first steps of the winner led to the main temple of the city-state where he sacrificed and devoted to the gods his wreath. The

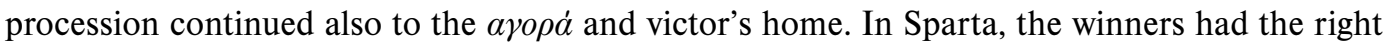
to march and fight next to the king. This was illustrated by the example of a Spartan wrestler who refused to lose in the final when to him there was offered a huge sum of money as a bribe. When they asked him after the race what he has now from his victory, he said that now he can fight in the battlefield before his king (Sábl, 1960, p. 149-150). In Alexandria, the winners became the members of the Musaeum (it could be said that it was some kind of an academy of science and art). In Athens, the victors received 500 drachmas (Plut., Solon 23.5), in Sybaris 100 drachmas, and later, according to Dio Chrysostom (De Gloria 1), the winners could received even $5 \operatorname{talets}^{20}(=$ 30000 drachmas $)^{21}$. For victors who came from Athens and according to Solo's census, this point was important not only because of the money but also for the reason that the possession of 500 drachmas meant that the man belonged to the highest class of society. In many cities the victors could eat for free until the end of their life in the $\pi \rho v \tau \alpha v \varepsilon \tilde{i} o v$. "Sporting" buildings were named after them and to most of them were offered an important position in the religious or city administration. A lot of the winners were worshiped as heroes, either during their life (e.g. Euthymos of Locri ${ }^{22}$ as son of god of the local river) or when they died (e.g. Theagenes of Thasos as son of Heracles, Polydamas of Skotoussa, Phillipos of Croton, Kleomedes of Astypalia). According to Bacchylides the winner could have every woman. The victor's names were on a roll of fame of each city-state and winners received special symbols of the city-states (different for each $\pi \dot{\lambda} \lambda l \varsigma$ ). Several victors also received honorary citizenship of other $\pi \dot{\lambda} \lambda \varepsilon \iota \varsigma$, and some of them were called "the citizens of all the world" (Drees, 1968, p. 106; Sábl, 1960, p. 149-150). Kings were allowed to have special coins made to commemorate their victories (Drees, 1968, p. 102), e.g. Gelon of Syracuse, Phillip II of Macedon. A very interesting fact is that Gelon did this after his victory at Olympia in $488 \mathrm{BC}$ in tethrippon but not after his victory in the important battle of Himera $\left(480 \mathrm{BC}^{23}\right)$. In ancient Greece, many legends were created about the victors (e.g. Koroibos, Milo, Theagenes, Euthymos) as well as about other great people: Homer, Empedocles, etc. According to Plato (Rep. 425D) and in his ideal state, the winner could be the guardian and this was a great honor - to be the guardian and the Olympic winner.

In regard to advantages and money, it is possible to compare the victors to present football stars (Zamarovský, 2000). However, as Thomson (1952) noted, although the winners received considerable honors, they must not want too much or even want to become gods and thus to be subject to $v \beta \rho \imath \varsigma$ (hybris). The winner with the honors was only one, the first, the other competitors fell into oblivion. In contrast to that the original Homers' warriors- $\dot{\theta} \theta \lambda \eta \tau \alpha l$ were awarded with prizes in the Ilias, even if they did not win. ${ }^{24}$

The organization of such a glamorous welcome in the $\pi \dot{\lambda} \lambda l \zeta$ had one big advantage - increasing the interest in physical activities and raising the love of "sport" for the youth. That is how the $\pi o ́ \lambda l \varsigma$ guaranteed the trained defenders of their homeland. This also had a very strong educational impact on the youth. The relationship to the Olympic winners, thus the transition from the status of an ordinary person to the status in which the $\dot{\alpha} \theta \lambda \eta \tau \alpha l$ entered, were basis of the Olympic education. Youths were inspired by the best of the examples, which were reflected by the $\dot{\alpha} \rho \imath \tau \varepsilon i \bar{\alpha}$

\footnotetext{
${ }^{20} 1$ talent was $26,2 \mathrm{~kg}$ of silver.

${ }^{21}$ At this time, 1 drachma was the price of 1 sheep and 500 drachmas was equal to the annual profit from the manor.

${ }^{22}$ He saved a girl and killed a black daemon with wolf's skin and a horrible gaze.

${ }^{23}$ This battle took place in the same day as the more famous battle of Salamis.

${ }^{24}$ This was also seen in other games, e.g. the Great Panathenia, where the winner received the best prize, but others received some smaller prizes - the second, third and even the fourth and fifth place.
} 
$\pi \rho o ́ \mu \alpha \chi o r$ (aristeia promachoi ${ }^{25}$ ) and also by the $\dot{\alpha} \rho \imath \sigma \tau \varepsilon i \bar{\alpha} \dot{o} \lambda v \mu \pi \imath o v i \bar{\kappa} \alpha \dot{i}$ (aristeia olympionikai) with this jointed collective and individual glory. As the basis of Olympism and Olympic education in antiquity, and without a doubt, we can name the relationship of ancient Greek culture and society to the Olympic victors.

The best Greek $\dot{\alpha} \theta \lambda \eta \tau \alpha i$, who achieved victories in all great Greek games - the Olympian, the Pythian, the Isthmian and the Nemean - received the honorary title the $\pi \varepsilon \rho i o \delta o v \bar{i} \kappa \eta \varsigma$ and they were celebrated by all contemporaries. The winners of the Panhellenic Games were also elites warriors or commanders. Spartan victors fought next to their kings (Garlan, 2005). As ideal examples we can show the best of the Greeks $\dot{\alpha} \theta \lambda \eta \tau \alpha i$, the wrestler Milo of Croton, called "the king

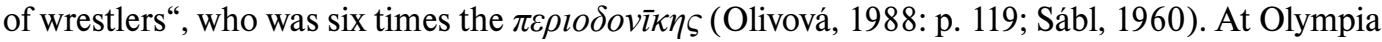
he won seven times (once as a junior at the age of 14), at Delphi also seven times, at Nemea nine times and at Isthmos ten times (Olivová, 1979). Before the end of his athletic career, Milo took part in a war against neighboring Sybaris, where he commanded the right wing, was dressed in lion ss skin and armed with a club to remind others of Heracles. He strongly helped to defeat the enemy (Miller, 2004; Newby, 2006; Potter, 2012; Sábl, 1968). Significant soldiers from Messenia were the $\delta \lambda v \mu \pi \imath$ ivī $\alpha \dot{i}$ Androclus, the victor of $\delta \rho \dot{\mu} \mu \rho \varsigma$ from 3rd Olympic Games, who died in de-

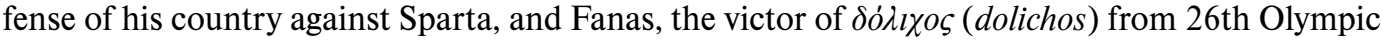
Games (Paus. 4.4.4; Golden, 2005: 10; Sábl, 1960). Another famous commander in the 7th cen-

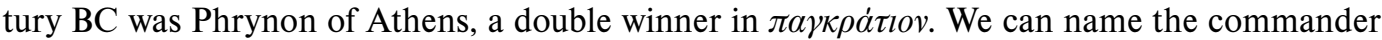
Alcibiades of Athens, the victor of $\tau \dot{\varepsilon} \theta \rho ı \pi \pi o v$ from the 91st Olympic Games, and pentathlete and the champion of disk throw Phayllus of Croton, who bought and armed a warship and alongside the Athenians he fought against the Persians and died at Salamis in the year 480 BC. We can also mention Philip II of Macedon, the father of Alexander the Great. Military and "sport" were closely linked in the antiquity, and so Olympic education and Olympism were dependent on both. All "sport"-military education led to the education of an ideal citizen in the sense of the education to "sport"-military and cultural ideals as the $\dot{\alpha} v \delta \rho \varepsilon i \bar{\alpha}$, the $\dot{\alpha} \rho \varepsilon \tau \dot{\eta}$, the $\dot{\alpha} \rho \imath \sigma \tau \varepsilon v \dot{\alpha}$, the $\dot{\alpha} \beta \rho o \sigma v \dot{v} \eta$, the $\kappa \alpha \lambda$ ка́ $\gamma \alpha \theta i \alpha$, the $\sigma \omega \phi \rho о \sigma \dot{v} \eta$, the $\tau \bar{\imath} \mu \eta^{26}$, etc.

\section{CONCLUSION}

Until the emergence of professionalism in ancient athletics was the essence of "sport" education and Olympism the areas known as free "sport", nudity, construction of "sports" buildings, organizing of many games and relation of society to the Olympic winners as well as leading the citizens to cultural and philosophical ideals like e.g. the $\dot{\alpha} v \delta \rho \varepsilon i \bar{\alpha}$, the $\dot{\alpha} \rho \varepsilon \tau \dot{\eta}$, the $\dot{\alpha} \rho \imath \sigma \tau \varepsilon v ́ \alpha$, the

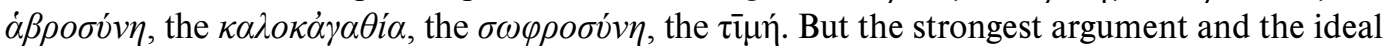
of the youth was definitely the status of the Olympic champion, his transition to this status and the relationship of the whole society to him. The victory at Olympia was not only an olive wreath, a red ribbon, a palm branch and the $\varphi v \lambda \lambda o \beta o \lambda i \alpha$ or a statue and an epinikion for some of them, but also a banquet at Olympia and a public announcement of the winner's name, family and the $\pi \delta$ í $\imath \varsigma$, free food at the expense of the city-state, a place in a cult or other important position after the end of his career, friendship with prominent persons and marriage with their daughters, likewise the protection after the fight when it was honest for the Olympic winner to be released without the ransom or for the Spartans honorable place next to the king in marching and struggle and especially the triumphal entry into the $\pi o ́ \lambda l \varsigma$ through a new hole in the walls. This last part

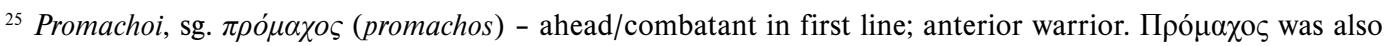
famous epithet of Greek goddness Athena.

${ }^{26}$ Andreia, arete, aristeia, habrosyne, kalokagathia, sophrosyne, time.
} 
of the honors to the winners was similar to Roman triumphs; a celebration of the one - the best - had to act the most powerful on the youth and thus it means the best way to educate children.

\section{References}

\section{Primary Sources}

Athen., Deipnos. = Athenaeus, Deipnosophists, vol. 3, Books 6-7. Transl. by C. B. Gulick (1929). Cambridge: Harvard University Press.

Cic., Flac. = M. Tullius Cicero, M. Tulli Ciceronis Orationes. Ed. by A. Clark (1909). Oxford: Typographeo Clarendoniano.

D. Chr. = Dionis Prusaensis Chrysostomum, Quae Exstant Omnia, Vols I \& II. Ed. by J. de Arnim (1893). Berlin: Weidmann.

Diod. Sic. = Diodorus Sicilus, Library of History, volume V, Books 12.41-13. Transl. by C. H. Oldfather (1950). Cambridge: Harvard University Press.

Hes., Th. = Hesiod, Theogony. In: Hesiod, The Homeric Hymns and Homerica. Ed. \& Transl. by H. G. Evelyn-White (1914). Cambridge: Harvard University Press \& London: William Heinemann.

Hom. II. = Homeros, Homer's Ilias, zweiter Teil : Gesang XI-XXIV. Ed. E. Naumann (1898). Leipzig: Velhagen \& Klasing.

Hom. Il. = Homer, Ílias. Transl. R. Mertlík (1980). Prague: Odeon.

Paus. = Pausanias, Cesta po Řecku I. Transl. H. Businská (1973). Prague: Svoboda.

Paus. $=$ Pausanias, Cesta po Řecku II. Transl. H. Businská (1974). Prague: Svoboda.

Paus. = Pausanias, Pausanias Description of Greece, 4 Volumes. Ed. \& Transl. by W. H. S. Jones \& H. A. Ormerod (1918). Cambridge: Harvard University Press \& London: William Heinemann.

Pind., O. = Pindar, The Odes of Pindar. Ed. \& Transl. by J. Sandys (1937). Cambridge: Harvard University Press \& London: William Heinemann.

Pind., O. / I. = Pindar, Odes. Transl. by D. A. Svarlien (1990). New Haven: Yale University Press.

Plat., Rep. = Plato, The Republic. In: Plato, Plato in Twelve Volumes, Vols. 5 \& 6. Transl. by P. Shorey (1969). Cambridge: Harvard University Press \& London: William Heinemann.

Plin., NH = Gaius Plinius Caecilius Secundus, C. Plini Secundi Naturalis Historiae, libri XXXVII, Vol. V. Libri XXXI - XXXVII. Ed. by K. Mayhoff (1897). Lipsiae: B. G. Teubner.

Plut., Mor. = Plutarch, Quaestiones Convivales. In: Plutarch, Moralia. Ed. G. N. Bernardakis (1892). Leipzig: Teubner.

Plut., Quaes. Conv. = Plutarch, Quaestiones Convivales. In: Plutarch, Plutarch's Morals. Transl. by W. W. Goodwin (1874). Boston: Little, Brown, and Company \& Cambridge: Press Of John Wilson and son.

Plut., Solon = Plutarch, Lycurgus. In: Plutarch, Plutarch's Lives, Vol. 1. Transl. by B. Perrin (1914). Cambridge: Harvard University Press \& London: William Heinemann.

Suet., Nero = Gajus Suetonius Tranquillus, Životopisy dvanácti císařů. Transl. by B. Ryba (1966). Prague: Státní nakladatelství krásné literatury a umění.

Thuc. = Thucydides, History of the Peloponnesian War, Volume 1. Ed. \&Transl. by B. Jowett (1881). Oxford: Clarendon Press. Vitr. $=$ Vitruvius Pollio, On Architecture. Ed. F. Krohn (1912). Lipsiae: B.G. Teubner.

Vitr. = Vitruvius, The Ten Books on Architecture. Transl. by M. H. Morgan (1914). Cambridge: Harvard University Press \& London: Humphrey Milford. Oxford University Press.

\section{Secondary Sources}

Bouzek, J. \& Ondřejová, I. (1989). Periklovo Řecko. Prague: Mladá fronta.

Cambiano, G. (2005). Cesta k dospělosti. In: Vernant, J.-P. (Ed.). Řecký člověk a jeho svět. Prague: Vyšehrad, pp. 77-103.

Drees, L. (1968). Olympia: Gods, Artists and Athletes. London: Pall Mall Press.

Garlan, Y. (2005). Člověk a válka. In: Vernant, J.-P. (Ed.). Řecký člověk a jeho svět. Prague: Vyšehrad, pp. 47-85.

Golden, M. (2005). Sport in the Ancient World from A to Z. London: Taylor \& Francis e-Library.

Grexa, J. (2008). Kalokagathia - staroveký ideál a novoveká realita. In: Šíp, R. (Ed.). Kalokagathia: ideál, nebo flatus vocis? Brno: Masarykova univerzita \& Paido. Pp. 33-41.

Grexa, J. (2009). Přehled světových dějin sportu. Brno: Masarykova univerzita.

Hogenová, A. (2000). Areté: Základ olympijské filozofie. Prague: Karolinum.

Hyde, W. W. (1921). Olympic Victor Monuments and Greek Athletic Art. Washington: Carnegie Institution.

Jaeger, W. (1986). Paideia: The Ideals of Greek Culture, volume III: The Conflict of Cultural Ideals in the Age of Plato. New York/ Oxford: Oxford University Press.

Jirásek, I. (2009). Nahota v kontextu pohybové kultury. In: Tělesná kultura, vol. 32, no 2. Olomouc: Faculty of Physical culture, Palacký University, pp. 7-19.

Kefalidou, E. (1999). Ceremonies of AthleticVictory in Ancient Greece: an Interpretation. In: Decker, W.; Ebert, J.; Sinn, U. \& I. Weiler (Eds.). Nikephoros: Zeitschrift für Sport und Kultur im Altertum, 12. Jahrgang. Hildesheim: Weidmann. Pp. 95-119.

Kössl, J. et alii (1982). Malá encyklopedie olympijských her. Prague: Olympia.

Kouřil, J. (2015). K problematice antického pentathlonu. In: Suchý, J. et al. (Eds.). Scientina Movens 2015 : Sborník př́ispěvků z mezinárodní studentské vědecké konference. Prague: Faculty of Physical Education and Sport, Charles University. Pp. 117-126. 
Kouřil, J. (2016). Athlétai a sportovní tituly antického světa. In: Tělesná kultura, 2016, roč. 39, č. 1, Olomouc: Palacký University, pp. 15-26.

Miller, S. G. (2004). Ancient Greek Athletics. New Haven \& London: Yale University.

Newby, Z. (2006). Athletics in the Ancient World. London: Bristol Classical Press.

Olivová, V. (1979). Lidé a hry: Historická geneze sportu. Prague: Olympia.

Olivová, V. (1988). Sport a hry ve starověkém světě. Prague: Artia.

Osborne, R. (2010). Dějiny klasického Řecka. Prague: Grada Publishing.

Pleket, H. W. (2012). The Reward of the Ancient Athlete. In: Petermandl, W. \& C. Ulf (Eds.). Nikephoros: Journal of Sports and Culture in Antiquity (Special Issue 2012: Youth - Sports - Olympic Games). Hildesheim: Weidmann. Pp. 131-134.

Potter, D. (2012). The Victor's Crown: How the Birth of the Olympics and the Rise of the Roman Games Changed Sport For Ever. London: Quercus.

Prach, V. (1998). Řecko-český slovník. Prague: Vyšehrad.

Sábl, V. (1960). Od Olympie k Římu 1960: Z dějin olympijských her. Prague: Sportovní a turistické nakladatelství.

Sábl, V. (1968). Hrdinové antických olympiád: Olympijské př́běhy a pověsti. Prague: Olympia.

Scheiner, J. E. (1891). Dějiny cvičení tělesných, díl l: Tělesná cvičení ve starém věku. Prague: own edition.

Schöbel, H. (1965). Olympia un seine Spiele. Leipzig: Sportverlag.

Šílený, T. (1947). Život v antickém Řecku. Prague: Jednota českých filologů v Praze.

Thomson, G. (1952). Aischylos a Athény: O původu umění ve starověkém Řecku. Prague: Rovnost.

Trianti, I. \& Valavanis, P. (2015). Olympia. Athens: Papadimas Ekdotiki.

Tyrš, M. (1968). Hod olympický. Prague: Olympia.

Weiler, I. (2012). Victory and "Bringer of Victory" Nike and Nikephoros. In: Petermandl, W. \& C. Ulf (Eds.). Nikephoros: Journal of Sports and Culture in Antiquity (Special Issue 2012: Youth - Sports - Olympic Games). Hildesheim: Weidmann. Pp. 21-22.

Zamarovský, V. (2003). Vzkříšení Olympie. Prague: Euromedia Group - Knižní klub - Erika.

\section{Corresponding author:}

PhDr. Jiří Kouřil, Ph.D.

Department of Classical Studies, Faculty of Arts, Masaryk University

Arna Nováka 1/1, 60200 Brno

213777@mail.muni.cz 